Basic Health Sciences

Poster

Abstract ID: 66

\title{
Quantitative evaluation of medium filth (najs mutawassitah) in halalan toyyibah food
}

\author{
Ibrahim Abu Bakar ${ }^{\mathrm{a}} \mid$ Ainin Azwani Abdul Rafa ${ }^{\mathrm{b}} \mid$ Norrakiah Abdullah Sani ${ }^{\mathrm{c}}$ \\ ${ }^{a}$ Department of Nutrition Science, International Institute for Halal Research and Training \\ (INHART), International Islamic University Malaysia, \\ ${ }^{b}$ Department of Nutrition Science, Kulliyyah of Allied Health Sciences, International Islamic \\ University Malaysia
}

${ }^{c}$ Food Science Program, School of Chemical Sciences and Food Technology, Universiti Kebangsaan Malaysia

Introduction: This study was conducted to evaluate the quantity of medium filth (najs mutawassitah) and the growth rate of faecal borne bacteria in self prepared fried rice toward the standardization of 'halalan toyyibah' food. Methods: The samples of fried rice were cooked with the application of hygienic practices. A specific quantity of human stools were then purposely inoculated into the samples. The growth curves of the bacteria were determined using NanoDrop 1000 UV-VIS Spectrophotometer at 630nm where the initial and end of lag times for each of the bacterial growth were determined. Results: The results showed that if the contamination of human stools in the food is in small quantity (1-2 drops), it may have no health risk at all (within lag time). If the human stools are in higher volume (more than 2 drops, or about $1 \mathrm{ml}$ ) then it may start to contaminate the food and could then lead to health risks. If foods are contaminated with small amounts (about $0.1 \mathrm{ml}$ ) of human stools and left at ambient temperature (about $37^{\circ} \mathrm{C}$ ) for about 4 hours, the same thing will happen. Conclusions: If the level of health risk is translated according to Shariah law, foods which are contaminated with higher amount (more than 2 drops, or about $1 \mathrm{ml}$ ) of human stools or contaminated with small amounts (1-2 drops) of human stools, but are left (about 4 hours) at ambient temperature can be considered as shubhah/makhrooh to be eaten.

KEYWORDS: Toyyibah food, najs mutawassitah, bacterial growth 